Jurnal Penyuluhan, Maret 2011 Vol. 7 No. 1

\title{
Karakteristik Adopter pada Masyarakat Nelayan Kampung Cipatuguran Palabuhanratu dalam Penerimaan Teknologi Baru
}

\author{
Characteristics of Adopters at Fishermen Society \\ Palabuhanratu Cipatuguran village in Acceptance of New Technology
}

Pepi Rospina Pertiwi, Idha Farida, Rinda Noviyanti

Dosen Program Studi Penyuluhan dan Komunikasi Pertanian

Universitas Terbuka

\begin{abstract}
In extension agriculture, the innovation introduction for goals is the important think especially if the innovation had appropriate with goals needed and its application to raising the goals welfare. This study aimed to explains the fisherman innovativeness level and the adopter characteristic category. Explanatory research design with survey method were used to collect data. The location were choosen with purposively in Kecamatan Palabuhanratu, Kabupaten Sukabumi, Jawa Barat. The population as a whole are all fisherman in Palabuhanratu, and 37 fisherman are chosen randomly as study samples. Data collection is using survey method, and are showed quantitivelly by frequently tabulation and bar chart. This study shows that the fisherman in Kampung Cipatuguran, Palabuhanratu is dominated by high-level in leaderships level, capital ownership, empaty level, abstraction level, dare to take a risk level, futuristic level, partisipation level, and communication activity. Base on asking all of respondents, the degree of innovation tryness was shown medium relatively, decision for adopt the innovation is relatively high, the fearness of take a risk is relatively high, the need of supporting agent of change is relatively high, the appropriate of take a decision is relatively low, the equal of social relationship is relatively high and the relationship with informal leader was is relatively low.
\end{abstract}

Key words: adopter, fisherman, innovation

\begin{abstract}
Abstrak
Dalam bidang penyuluhan pertanian, pengenalan inovasi untuk pencapaian tujuan merupakan suatu hal yang penting, terutama jika inovasi sesuai dengan tujuan yang diperlukan dan berperan untuk meningkatkan kesejahteraan. Penelitian ini bertujuan untuk menjelaskan tingkat inovasi nelayan dan kategori karakteristik adopter. Penelitian ini dilakukan dengan menggunakan metode survei deskriptif. Lokasi penelitian dipilih secara purposif di Kecamatan Pelabuhanratu, Kabupaten Sukabumi, Jawa Barat. Populasi penelitian adalah semua nelayan di Pelabuhanratu, dan 37 nelayan yang dipilih secara acak sebagai sampel penelitian. Pengumpulan data menggunakan metode survei, dan disajikan secara kuantitatif dengan tabel frekuensi dan grafik. Studi ini menunjukkan bahwa nelayan di Kampung Cipatuguran, Pelabuhanratu didominasi oleh para elit di tingkat pemimpin, kepemilikan modal, tingkat empati, tingkat abstraksi, berani mengambil risiko, tingkat futuristik, tingkat partisipasi masyarakat, dan aktivitas komunikasi. Berdasarkan tanggapan responden, tingkat ketercobaan inovasi relatif sedang, keputusan untuk mengadopsi inovasi relatif tinggi, kemampuan mengambil risiko relatif tinggi, kebutuhan untuk mendukung agen perubahan relatif tinggi, kesesuaianpengambilan keputusan relatif rendah, kesetaraan hubungan sosial relatif tinggi dan hubungan dengan pemimpin informal relatif rendah.
\end{abstract}

Kata kunci : adopter, inovasi, nelayan.

\section{Pendahuluan}

Salah satu dampak penyebaran inovasi pada suatu masyarakat adalah terbentuknya tingkatan kelompok penerima inovasi. Ketika suatu inovasi digulirkan, sebagian orang merespon dan tertarik dengan inovasi tersebut, sebagian lainnya mungkin tidak peduli sama sekali. Di antara kedua kelompok tersebut terdapat orang yang memiliki tingkatan res- pon yang berbeda-beda, artinya ada proses berpikir dari diri seseorang yang menjadi faktor penentu diterimanya atau ditolaknya inovasi oleh orang tersebut (Deptan, 2001).

Dalam ilmu penyuluhan dan komunikasi pertanian, pengelompokan masyarakat berdasarkan penerimaan inovasi dikenal dengan istilah kategori adopter, yang diklasifikasikan oleh Rogers dan Shoemaker (1995) menjadi 5 
(lima) jenis, yaitu: (1) inovator, (2) early adopter, (3) early majority, (4) late majority dan (5) laggard. Menurut Rogers dan Shoemaker, kelima kategori ini memiliki perbedaan yang cukup nyata dalam menyikapi teknologi baru, diantaranya berbeda dalam: tingkat kesukaan untuk mencoba teknologi baru, tingkat keputusan dalam penerapan teknologi baru, tingkat kebutuhan akan dukungan pihak lain dalam menerapkan teknologi baru serta tingkat ketepatan dalam mengambil keputusan adopsi.

Selain itu, Rogers dan Shoemaker (1995) mengemukakan bahwa perbedaan kontinum dapat dilihat antara masyarakat mana yang lebih inovatif dan kurang inovatif, yang diuraikan dalam karakteristik keinovatifan tersebut menjadi tiga bagian, yaitu: (1) Karakteristik sosial ekonomi, meliputi: status sosial yang lebih tinggi, tingkat mobilitas yang lebih besar, lahan yang lebih luas, modal yang lebih banyak, mempunyai pekerjaan yang lebih spesifik serta lebih berorientasi pada komersialisasi produk. (2) Karakteristik individu yang diperlihatkan dengan: tingkat pendidikan, tingkat kepemimpinan, mobilitas, empati yang besar, tidak/kurang dogmatis, kemampuan abstraksi besar, rasionalis, intelegensinya tinggi, lebih berkenan pada perubahan, mau mengambil resiko dan tidak percaya pada nasib (futuristik). (3) Karakteristik komunikasi yang meliputi: tingkat partisipasi sosial yang tinggi, sering mengadakan komunikasi interpersonal, sering mengadakan hubungan sosial dengan orang asing dan dengan agen pembaharu, sering memanfaatkan media massa untuk mencari informasi, memiliki tingkat kepemimpinan yang tinggi serta senang berada pada sistem yang bernorma modern.

Masyarakat nelayan memiliki karakteristik yang unik yang membedakannya dengan petani. Ciri tersebut adalah adanya lahan yang digunakan bersama dan terbuka untuk umum (open access), sehingga nelayan memiliki kesempatan yang sama dalam mencari penghasilan di laut. Namun demikian yang membedakan strata sosial mereka adalah jenis alat tangkap yang dimiliki. Dengan demikian kegiatan penyuluhan yang memotivasi nelayan untuk menerima dan menerapkan inovasi sangat penting dilakukan bagi masyarakat nelayan.
Pada masyarakat nelayan, pengadopsian inovasi umumnya berupa teknologi penangkapan ikan. Penerima inovasi tersebut terdiri atas berbagai kalangan, namun yang terutama merespon biasanya dari golongan atas, atau golongan yang memiliki akses dan modal yang cukup untuk memperoleh inovasi (Chambers dalam hasil penelitian Pertiwi, 1994). Namun demikian kalangan pertama tersebut dapat membuka jalan bagi kelompok masyarakat lain untuk ikut mengadopsi inovasi. Jeda waktu penerimaan inovasi pada tiap-tiap orang tersebut berbeda-beda, sehingga akan menimbulkan pola waktu penerimaan inovasi yang selanjutnya akan mengelompokkan penerima inovasi berdasarkan karakteristik yang mempengaruhinya. Selanjutnya dalam suatu periode adopsi inovasi tertentu, dapat diketahui pula komposisi kelompok penerima inovasi yang terdapat pada masyarakat nelayan tersebut.

Beberapa pertanyaan yang muncul berdasarkan uraian di atas adalah, bagaimanakah gambaran masyarakat nelayan ditinjau dari karakteristik keinovatifannya? Seperti apa karakteristik masyarakat nelayan sebagai adopter inovasi terkait penerimaan teknologi baru?

\section{Metode Penelitian}

Artikel ini ditulis berdasarkan hasil penelitian tahun 2007 yang menganalisis tentang karakteristik keinovatifan masyarakat nelayan dalam kaitannya dengan pola karakteristik adopter, sebagai suatu kasus yang diambil dari para nelayan di kampung Cipatuguran, Kelurahan Palabuhanratu. Sukabumi. Penelitian ini dilakukan dengan mengidentifikasi karakteristik masyarakat nelayan berdasarkan variabelvariabel sebagai berikut: (a) Karakteristik individu (tingkat pendidikan, tingkat kepemimpinan dan tingkat kekosmopolitan) dan (b) Karakteristik komunikasi (aktivitas komunikasi, tingkat keterdedahan terhadap media massa dan keikutsertaan dalam penyuluhan); serta mengidentifikasi karakteristik kategori adopter yang dikemukakan oleh Rogers dan Shoemaker berdasarkan sikap nelayan terhadap teknologi baru (tingkat kesukaan untuk mencoba teknologi baru, tingkat keputusan dalam penerapan teknologi baru, tingkat kebutuhan 
akan dukungan pihak lain dalam menerapkan teknologi baru serta tingkat ketepatan dalam mengambil keputusan adopsi).

Rancangan penelitian ini berbentuk eksplanatory research yang bertujuan menggambarkan karakteristik kategori adopter melalui identifikasi karakteristik penerima inovasi berdasarkan ciri-ciri kategori adopter. Lokasi penelitian dipilih secara sengaja, yaitu di wilayah Kecamatan Palabuhanratu, Sukabumi, Jawa Barat. Populasi dalam penelitian ini adalah semua nelayan yang berada di kampung nelayan terpilih di wilayah Palabuhanratu. Kampung yang terpilih yaitu Kampung Cipatuguran, merupakan kampung nelayan yang terletak di pinggir pantai. Responden diambil secara random dengan mendekati proporsi yang ada, sehingga terpilih 37 nelayan dari Kampung Cipatuguran.

Metode pengumpulan data yang digunakan adalah metode survey dengan pendekatan kuantitatif. Uji korelasi rank Spearman $\left(\mathrm{r}_{\mathrm{s}}\right)$ digunakan untuk menguji hubungan antar variabel. Sebagai pendukung, penelitian ini juga menggunakan pendekatan kualitatif untuk memperoleh informasi sebanyak mungkin, melalui pengamatan dan wawancara mendalam terhadap informan atau beberapa responden terpilih. Penelitian ini dilakukan dengan mengidentifikasi karakteristik masyarakat nelayan berdasarkan variabel-variabel sebagai berikut: (a) karakteristik individu $\left(\mathrm{X}_{1}\right)$ dan (b) karakteristik komunikasi $\left(\mathrm{X}_{2}\right)$; serta mengidentifikasi karakteristik kategori (Y).

\section{Gambaran Umum Wilayah Penelitian}

Nelayan di wilayah Palabuhanratu memiliki heterogenitas dalam penggunaan teknologi alat tangkap. Berdasarkan data Pelabuhan Perikanan Nusantara, pada tahun 2005 nelayan yang beraktifitas berjumlah sekitar 3500 orang, dengan alat tangkap bervariasi seperti: pancing, payang, bagan, jaring, purse seine dan lain-lain. Namun pada nelayan tradisional, alat tangkap yang banyak digunakan adalah pancing, payang dan bagan yang dibantu dengan jaring sederhana.

Dalam program penyuluhan di bidang perikanan, peningkatan teknologi alat tangkap bagi nelayan tradisional atau nelayan kelas menengah ke bawah terus diupayakan. Menurut penyuluh perikanan di wilayah Palabuhanratu, pada dasarnya hampir semua nelayan di Palabuhanratu bisa memproduksi alat tangkap sederhana secara sendiri, seperti pancing dan jaring. Kendala terbesar bagi nelayan pada umumnya adalah sulitnya mencari wilayah perairan yang mengandung banyak ikan tangkapan. Hal ini karena alat tangkap sederhana hanya dapat melaut dalam zona tangkapan ikan yang terbatas, dengan jumlah ikan yang sedikit. Untuk itu, kegiatan penyuluhan yang dilakukan pada saat ini mengarah pada pengenalan dan introduksi rumpon, berbentuk suatu alat/perangkat yang dapat menjadi tempat berkumpulnya ikan di kedalaman laut tertentu. Dengan adanya rumpon, nelayan dapat menetapkan wilayah tangkapan dengan efektif sehingga kemungkinan besar dapat memperoleh hasil tangkapan pada saat melaut.

\section{Karakteristik Keinovatifan Masyarakat Nelayan}

Karakteristik pribadi yang pertama adalah tingkat pendidikan yang diukur dari tingkat pendidikan formal responden yang dapat diketahui bahwa tingkat pendidikan responden di Pelabuhanratu dominan pada tingkat pendidikan tamat Sekolah Dasar (SD) yaitu sebesar 40,5\% dan responden yang tidak tamat SD sebesar 32,4\%. Hal ini menggambarkan kondisi pendidikan formal para responden relatif rendah atau tidak terlalu diperhatikan oleh mereka dalam menekuni karir sebagai nelayan. Kondisi ini sesuai dengan pendapat Pangemanan, dkk (2002) yang mengemukakan bahwa kondisi umum masyarakat nelayan dicirikan dengan tingkat pendidikan yang rendah.

Karakteristik pribadi yang kedua adalah tingkat kepemimpinan. Dalam mengukur tingkat kepemimpinan responden dapat dirumuskan beberapa indikator yaitu kepemilikan jabatan sosial yang diduduki responden di masyarakat, kemampuan responden dalam mempengaruhi orang lain, dan kemampuan responden dalam membuat keputusan. Dalam penelitian ini sebesar $89,2 \%$ responden menyatakan bahwa mereka tidak memiliki jabatan sosial di wilayahnya. Responden dominan 
lebih banyak bekerja hanya sebagai nelayan dan tidak memiliki jabatan apapun seperti ketua RT, tokoh masyarakat, dan semacamnya. Dengan bekerja sebagai nelayan, membuat kondisi mereka tidak memungkinkan untuk mengurusi kegiatan sosial.

Dalam mempengaruhi orang lain, sejumlah $59,5 \%$ responden mengakui memiliki kemampuan ini, sehingga dapat dikatakan kemampuan responden dalam mempengaruhi orang lain relatif cukup tinggi. Hal ini sesuai dengan pernyataan para responden yang sering bertukar pikiran dengan teman sesama nelayan dan berdiskusi tentang perkembangan usaha perikanan baik dari harga, cuaca ataupun kondisi lainnya. Para responden cenderung mempercayai temannya sendiri dibandingkan orang lain.

Dalam membuat keputusan, para responden relatif tinggi memiliki kemampuan ini yakni sebesar sebesar $47 \%$ memiliki kemampuan yang tinggi, sebesar $41 \%$ berkemampuan sedang, dan $12 \%$ berkemampuan rendah. Angka ini menunjukkan bahwa kemampuan responden dalam membuat keputusan relatif cukup baik. Para responden tidak mengalami kesulitan yang berarti dalam menentukan kemauannya. Mereka cenderung optimis dalam menjalankan pekerjaannya. Responden mengakui bahwa dalam menentukan waktu kapan mereka akan pergi melaut diputuskan oleh mereka sendiri tanpa paksaan atau anjuran dari pihak lain. Kepercayaan diri mereka cukup tinggi untuk menentukan sendiri keputusan-keputusan yang berhubungan dengan mencari ikan.
Tingkat kekosmopolitan responden dapat diukur dengan beberapa indikator yaitu: intensitas responden pergi ke luar desa, intensitas responden menerima informasi dari luar desa, dan intensitas hubungan responden dengan orang lain di luar desa. Sebaran responden berdasarkan tingkat kekosmopolitan dapat dilihat pada Tabel 1 .

Pada Tabel 1 dapat diketahui bahwa responden lebih dominan tidak pernah pergi ke luar desa, yaitu sebesar 48,6\%. Hal ini menandakan hubungan antara nelayan responden dengan lingkungan di luar desanya relatif kurang intens atau rendah. Para nelayan biasanya disibukkan dengan kegiatan melaut, menjual hasil tangkapan, membuat jaring sendiri, dan kemudian beristirahat di rumah setelahnya. Adapun intensitas nelayan dengan frekuensi kurang dari 3 kali adalah sebesar 32,4\%.

Dalam kaitannya dengan intensitas responden untuk menerima informasi dari luar desa, ternyata sejumlah $43,2 \%$ atau sebanyak 16 orang yang menyatakan bahwa kurang dari 3 kali dalam sebulan mereka menerima informasi dari luar desa. Hal ini menandakan keterdedahan para responden terhadap informasi masih relatif sedang, tidak terlalu rendah dan tidak terlalu tinggi. Jadi, walaupun intensitas responden pergi ke luar desa relatif rendah namun dalam hal penerimaan informasi dapat dikatakan cukup baik. Informasi yang mereka dapatkan dapat saja berasal dari nelayan lain yang pergi ke luar desa atau nelayan luar yang membawanya masuk ke dalam desa mereka.

Tabel 1. Sebaran Responden berdasarkan Tingkat Kekosmopolitan

\begin{tabular}{|c|c|c|c|}
\hline Karakteristik & Kategori & Jumlah & Persentase $(\%)$ \\
\hline \multirow[t]{3}{*}{ Intensitas responden pergi ke luar desa } & Tidak pernah & 18 & 48.6 \\
\hline & $<3$ kali & 12 & 32.4 \\
\hline & $\geq 3$ kali & 7 & 18.9 \\
\hline Total & & 37 & 100.0 \\
\hline Intensitas responden menerima informasi & Tidak pernah & 14 & 37.8 \\
\hline \multirow[t]{2}{*}{ dari luar desa } & $<3$ kali & 16 & 43.2 \\
\hline & $\geq 3$ kali & 7 & 18.9 \\
\hline Total & & 37 & 100.0 \\
\hline Intensitas hubungan responden dengan & Tidak pernah & 20 & 54.1 \\
\hline \multirow[t]{2}{*}{ orang di luar desa } & $<3$ kali & 13 & 35.1 \\
\hline & $\geq 3$ kali & 4 & 10.8 \\
\hline Total & & 37 & 100.0 \\
\hline
\end{tabular}


Tabel 2. Sebaran Responden berdasarkan Aktivitas Komunikasi

\begin{tabular}{llccccc}
\hline \multirow{2}{*}{ No } & \multicolumn{1}{c}{ Pernyataan } & \multicolumn{3}{c}{ Jawaban (jumlah dan \%) } & \multirow{2}{*}{ Jumlah } \\
\cline { 2 - 5 } & & TS & KS & S & SS & \\
\hline 1 & Sering berkomunikasi dengan sesama & $1(2,7)$ & $0(0)$ & $27(73,0)$ & $9(24,3)$ & $37(100)$ \\
& nelayan & & & & & \\
2 & Sering berkomunikasi dengan penyuluh & $15(40,5)$ & $10(27,0)$ & $10(27,0)$ & $2(5,4)$ & $37(100)$ \\
3 & Mau berkomunikasi dengan orang yang & $2(5,4)$ & $14(37,8)$ & $19(51,4)$ & $2(5,4)$ & $37(100)$ \\
& baru kenal & & & & \\
4 & Selalu mau bertanya tentang pekerjaan & $1(2,7)$ & $4(10,8)$ & $28(75,7)$ & $4(10,8)$ & $37(100)$ \\
5 & $\begin{array}{l}\text { Selalu memberi jawaban atas } \\
\text { pertanyaan orang lain }\end{array}$ & $0(0)$ & $8(21,6)$ & $26(70,3)$ & $3(8,1)$ & $37(100)$ \\
\hline
\end{tabular}

Keterangan: TS = Tidak Setuju, KS = Kurang Setuju, S = Setuju, SS = Sangat Setuju

Indikator tingkat kekosmopolitan responden yang terakhir adalah intensitas hubungan responden dengan orang di luar desa. Tabel 1 menunjukkan bahwa Dari keseluruhan responden, yang menyatakan mereka tidak pernah berhubungan dengan orang di luar desa adalah sebesar 54,1\%. Dengan demikian dapat dikatakan intensitas hubungan responden dengan orang luar desa relatif masih rendah. Kurangnya alat transportasi di wilayah tersebut juga turut mempengaruhi mobilitas nelayan untuk pergi keluar desa. Lokasi yang agak terpencil dan hanya ada angkutan kendaraan bermotor yang tersedia dapat menghambat nelayan untuk berhubungan dengan orang lain. Mereka cenderung berkumpul di dalam desanya sambil membuat alat jaring ikan yang baru atau hanya sekedar untuk memperbaikinya.

Jika dilihat dari ketiga indikator di atas, maka dapat disimpulkan tingkat kekosmopolitan responden cenderung rendah.

\section{Karakteristik Keinovatifan Masyarakat Nelayan}

Aktivitas komunikasi yang dimaksud dalam penelitian ini adalah keinginan nelayan dalam melakukan kegiatan komunikasi dengan pihak lain. Dari Tabel 2 terlihat bahwa responden lebih sering berkomunikasi dengan sesama nelayan daripada dengan penyuluh. Hal ini ditunjukkan dengan jawaban "setuju" dan "sangat setuju" yang tinggi $(73,0 \%$ dan $24,3 \%$ ) ketika ditanya sering atau tidaknya berkomunikasi dengan nelayan. Hanya beberapa nelayan yang menyatakan sering berkomunikasi dengan penyuluh, diduga karena kegiatan penyuluhan memang jarang dilaku- kan di wilayah ini, atau nelayan merasa segan untuk berkomunikasi dengan penyuluh.

Namun demikian, nelayan cenderung mau berkomunikasi dengan orang yang baru dikenal, sepanjang tidak terlepas dari urusan yang berkaitan dengan pekerjaan mereka. Hal ini ditunjukkan oleh jawaban "setuju" yang tinggi atas pernyataan bahwa responden selalu mau bertanya tentang hal-hal yang berkaitan dengan pekerjaan $(75,7 \%)$ atau memberi jawaban atas pertanyaan orang lain seputar masalah pekerjaan melaut (70,3\%).

\section{Tingkat Keterdedahan terhadap Media Massa}

Tingkat keterdedahan terhadap media merupakan intensitas nelayan mengakses media dalam sebulan, guna mencari berita yang berhubungan dengan pekerjaannya. Media massa yang umum digunakan oleh masyarakat nelayan antara televisi, radio dan surat kabar, sehingga penelitian ini memfokuskan pendapat responden dalam mengakses ketiga media ini.

Hasil penelitian menunjukkan bahwa tingkat keterdedahan responden terhadap media massa sangat rendah. Keadaan tersebut ditunjukkan dengan persentase yang tinggi pada jawaban responden yang "tidak pernah" mengakses media massa $(91,9 \%)$ tidak pernah mendengarkan siaran radio, $83,8 \%$ tidak pernah menonton televisi, dan $81,1 \%$ tidak pernah membaca surat kabar) tentang hal-hal yang berkaitan dengan pekerjaan mereka, seperti berita perikanan, teknologi penangkapan ikan, dan lain-lain.

Pada kenyataannya, nelayan sangat membutuhkan informasi. Hasil penelitian menunjukkan bahwa 97,3\% menyatakan sangat 
membutuhkan informasi yang berkaitan dengan mata pencaharian mereka. Jenis informasi yang diinginkan antara lain tentang: teknologi alat tangkap (40,5\%), teknik melaut $(13,5 \%)$ dan cara memperoleh modal $(13,5 \%)$. Selebihnya jenis informasi yang dibutuhkan adalah tentang harga ikan dan teknik pengolahan hasil perikanan.

Tingkat keterdedahan responden yang rendah terhadap media, tidak menyurutkan responden untuk mencari informasi. Sumber informasi yang banyak digunakan oleh responden adalah rekan sesama nelayan, penyuluh, media televisi dan lain-lain. Sebanyak $48,6 \%$ responden mencari informasi dari sesama nelayan, $8,1 \%$ mencari informasi dari penyuluh dan $8,1 \%$ dari televisi. Selebihnya mencari informasi dari ketiga sumber tersebut, bahkan ada yang memperoleh informasi dari pengepul ikan.

\section{Tingkat Keikutsertaan dalam Penyuluhan}

Tingkat keikutsertaan dalam penyuluhan merupakan intensitas nelayan dalam mengikuti kegiatan penyuluhan dan pelatihan dalam setahun. Menurut nelayan, kegiatan penyuluhan di wilayah tempat tinggal nelayan tidak dilakukan secara teratur. Kegiatan penyuluhan yang teratur pernah dilakukan sekitar 10-15 tahun yang lalu, sewaktu para nelayan dilokalisasikan pertama kali di wilayah tersebut oleh pemerintah. Pada saat itu kelompok nelayan di lokasi baru banyak mendapat perhatian, terutama saat pengenalan motor tempel dan perahu fiber. Namun sekarang penyuluhan pertanian jarang dilakukan di lokasi tempat tinggal nelayan. Kegiatan penyuluhan perikanan hanya diselenggarakan di kantor cabang dinas perikanan.

Hasil penelitian menunjukkan bahwa hanya $10,8 \%$ responden yang pernah mengikuti kegiatan penyuluhan paling tidak 3 kali dalam setahun, serta $8,1 \%$ yang mengikuti kegiatan pelatihan paling tidak 3 kali dalam setahun. Sebagian besar responden bahkan tidak pernah mengikuti kegiatan penyuluhan dan pelatihan. Responden yang mengikuti kegiatan penyuluhan dan pelatihan adalah nelayan yang memiliki hubungan baik dengan luar desa dan tergolong sebagai tokoh masya- rakat. Kegiatan penyuluhan yang dilakukan adalah pemberian informasi tentang rumponisasi, atau yang sedang tren adalah tentang formalin. Adapun kegiatan pelatihan biasanya seputar teknologi pengolahan hasil perikanan.

Faktor keanggotaan dalam Kelompok Tani-Nelayan (KTN) juga mempengaruhi intensitas nelayan dalam mengikuti kegiatan penyuluhan. Sekitar 14 responden $(37,8 \%)$ menyatakan diri sebagai anggota KTN yang dibentuk sekitar 5-15 tahun yang lalu. Selebihnya $(62,2 \%)$ tidak pernah menjadi anggota KTN. Dari 14 anggota KTN, 9 orang sudah menjadi anggota KTN lebih dari 10 tahun, sedangkan sisanya hanya sekitar 1-10 tahun. KTN yang dibentuk terakhir kali adalah KTN Bahari, merupakan kelompok nelayan pancing. Namun kegiatan penyuluhan saat ini sudah jarang dilakukan.

\section{Karakteristik Adopter Masyarakat Nelayan}

Karakteristik adopter yang diuraikan dalam penelitian ini mengacu pada ciri-ciri karakteristik kategori adopter terkait penerimaan dan penerapan teknologi baru, sebagaimana yang diungkapkan oleh Rogers dan Schoemaker (1995). Hal-hal terkait karakteristik adopter diuraikan berdasarkan komponen tingkat kesukaan untuk mencoba teknologi baru, tingkat keputusan dalam penerapan teknologi baru, tingkat kebutuhan akan dukungan pihak lain dalam menerapkan teknologi baru serta tingkat ketepatan dalam mengambil keputusan adopsi.

Teknologi penangkapan ikan selalu berkembang dari waktu ke waktu. Penyebaran teknologi ini dapat cepat tersebar di kalangan masyarakat nelayan. Keterdekatan tempat tinggal dan kesamaan waktu pergi melaut dari tempat yang sama menjadi faktor kemudahan tersebarnya berita mengenai alat tangkap baru.

Tabel 3 memperlihatkan bahwa hampir setengahnya dari responden tidak terlalu suka mencoba teknologi/alat tangkap baru, sehingga kadang-kadang saja mereka mencoba jika ada alat tangkap baru. Beberapa responden menyebutkan bahwa mereka telah merasa nyaman dengan alat tangkap yang mereka punyai sebelumnya, dan telah mereka kuasai 
penggunaannya. Responden lain ada yang menyatakan bahwa mereka akan melihat-lihat situasi terlebih dahulu untuk mencoba alat tangkap baru, juga melihat kondisi keuangan mereka. Bagi $35,1 \%$ responden yang menjawab suka mencoba teknologi alat tangkap yang baru, cukup beralasan karena mereka ingin memperoleh hasil tangkapan yang lebih baik. Hanya sedikit nelayan yang sangat gemar mencoba teknologi baru. Bagi responden golongan ini, apapun alat tangkap baru, asalkan mudah tersedia pasti akan dicobanya.

Tabel 3. Sebaran Responden Berdasarkan Tingkat Kesukaan Mencoba Teknologi Baru

\begin{tabular}{llcc}
\hline No & Tingkat kesukaan & N & $\%$ \\
\hline 1 & Tidak suka & 3 & 8,1 \\
2 & Kadang-kadang & 17 & 45,9 \\
3 & Suka & 13 & 35,1 \\
4 & Sangat suka & 4 & 10,8 \\
\hline & Jumlah & 37 & 100,00 \\
\hline
\end{tabular}

Jawaban di atas dapat memperlihatkan kecenderungan tingkat adopter yang dimiliki nelayan. Nelayan yang sangat suka mencoba alat tangkap baru cenderung mencerminkan sifat inovator, nelayan yang menjawab "suka" dapat pula mencerminkan karakteristik pelopor walaupun mungkin tidak sepenuhnya bersifat demikian. Nelayan yang menjawab kadang-kadang, berjumlah paling banyak dan jumlah ini mencerminkan persentase yang wajar bagi kategori penerap awal dan penerap akhir. Adapun jumlah responden yang sangat sedikit adalah mereka yang menjawab sama sekali tidak suka mencoba, cenderung memperlihatkan sifat adopter yang sangat lamban.

Sebagai orang yang berjiwa wirausaha, nelayan acapkali harus memutuskan untuk mengambil dan menerapkan teknologi baru untuk mengembangkan usahanya (dalam hal ini terutama untuk meningkatkan produktivitas ikan yang ditangkapnya). Pola pengambilan keputusan tersebut berbeda-beda dalam sekelompok nelayan. Pada masyarakat kampung Cipatuguran, perbedaan ini terlihat dari jawaban responden tentang keputusan untuk menerapkan teknologi baru (Tabel 4).
Tabel 4. Sebaran Responden Berdasarkan Keputusan untuk Menerapkan Teknologi Baru

\begin{tabular}{llcc}
\hline No & \multicolumn{1}{c}{ Keputusan } & N & $\%$ \\
\hline 1 & Tidak mau menerapkan & 2 & 5,4 \\
2 & Setelah orang lain & 11 & 29,7 \\
& menerapkan & 9 & 24,3 \\
3 & Pikir-pikir dulu & 4 & 10,8 \\
4 & Meneliti dulu & 11 & 29,7 \\
5 & Langsung menerapkan & 37 & 100,0 \\
\hline & Jumlah & & \\
\hline
\end{tabular}

Berdasarkan Tabel 4, terlihat sejumlah 29,7\% nelayan akan langsung menerapkan jika ada alat-alat tangkap baru di wilayah mereka. Keadaan ini cukup menarik, karena ternyata nelayan memiliki keberanian yang tinggi untuk beresiko atas keputusannya. Jawaban ini memperlihatkan kecenderungan jiwa inovator pada diri nelayan.

Sekitar 10,8\% menyebutkan akan meneliti terlebih dahulu sebelum memutuskan penerapan alat tangkap baru, sedangkan 24,3\% menyebutkan akan memikirkan terlebih dahulu. Kategori pelopor diperlihatkan dari jawaban responden yang akan meneliti terlebih dahulu suatu alat tangkap baru, baik dari segi keberhasilannya, kekuatannya maupun kemudahan memperolehnya. Dalam hal ini Jumlah responden pelopor relatif lebih kecil dibanding responden yang berjiwa inovator. Adapun jumlah responden yang memperlihatkan kecenderungan sebagai penerap awal terlihat dari responden yang akan memikirkan dahulu untuk memutuskan penerapan teknologi baru.

Selanjutnya, sebaran normal terlihat dari responden yang menjawab akan memutuskan untuk adopsi bila masyarakat telah banyak yang menerapkan alat tangkap baru $(29,7 \%)$. Hal ini karena mereka ingin melihat keberhasilan nelayan lain yang telah lebih dulu menggunakan alat tangkap baru. Sedangkan kaum penolak alat tangkap hanya 5,4\% dari keseluruhan responden.

\section{Tingkat Kebutuhan akan Dukungan Pihak Lain dalam Menerapkan Teknologi Baru}

Dalam membuat keputusan untuk menerapkan alat tangkap baru, sering terdapat nelayan yang mencari dukungan terlebih dahulu kepada orang-orang di sekitarnya. Keberadaan 
penyuluh, tokoh masyarakat atau panutan sangat diperlukan bagi nelayan yang jenis ini. Hasil penelitian memperlihatkan bahwa hanya sedikit nelayan yang tidak memerlukan dukungan atau saran siapapun untuk mengambil keputusan $(16,2 \%)$. Jawaban ini memperlihatkan kecenderungan golongan inovator, kelompok yang benar-benar berani mengambil resiko atas apa yang diputuskannya.

Tabel 5. Sebaran Responden Berdasarkan Kebutuhan akan Dukungan/Saran dalam Menerapkan Teknologi Baru

\begin{tabular}{clcc}
\hline No & \multicolumn{1}{c}{$\begin{array}{c}\text { Kebutuhan akan } \\
\text { Dukungan }\end{array}$} & $\mathrm{N}$ & $\%$ \\
\hline 1 & Tidak peduli & 3 & 8,1 \\
2 & $\begin{array}{l}\text { Cenderung tergantung } \\
\text { lingkungan }\end{array}$ & 14 & 37,8 \\
3 & $\begin{array}{l}\text { Butuh dukungan orang lain } \\
\text { Tidak terlalu butuh } \\
\text { dukungan }\end{array}$ & 6 & 37,8 \\
\hline & Jumlah & 37 & 10,2 \\
\hline
\end{tabular}

Hasil penelitian memperlihatkan keseimbangan jawaban antara responden yang membutuhkan dukungan orang lain dan responden yang cenderung tergantung pada keadaan lingkungan/masyarakat umum (masing-masing $37,8 \%$ ). Responden yang membutuhkan dukungan/saran orang lain memperlihatkan kecenderungan karaktersitik pelopor dan penerap awal, sedangkan responden yang tergantung pada lingkungan menunjukkan karakteristik penerap akhir. Jawaban responden dalam komponen ini memperlihatkan sebaran yang normal. Jawaban terkecil, sebanyak $8,1 \%$ responden menjawab tidak peduli pada dukungan orang lain atau keadaan masyarakat, menunjukkan karakteristik kelompok lamban atau bahkan penolak teknologi baru. Usia responden kelompok terkecil ini tergolong tua (di atas 50 tahun), sehingga diduga kelompok ini sangat menghargai masa lalunya sebagai acuan cara mereka bekerja.

\section{Tingkat Ketepatan dalam Mengambil Keputusan Adopsi}

Terdapat variasi yang membentuk sebaran yang kurang normal dalam jawaban ini. Dilihat dari Tabel 6, jumlah yang tinggi, yaitu sebanyak $35,1 \%$ responden menyebutkan bahwa mereka belum tentu tepat dalam setiap keputusan untuk menggunakan alat tangkap baru, karena ternyata hasil dan jenis tangkapan tidak sesuai dengan yang diharapkan. Namun demikian mereka mengaku tidak menyesal, karena beranggapan bahwa nelayan harus berani menerima resiko apapun.

\begin{tabular}{clcc} 
Tabel 6. & $\begin{array}{l}\text { Sebaran Responden } \\
\text { Ketepatannya dalam } \\
\text { Keputusan Adopsi }\end{array}$ & $\begin{array}{c}\text { Berdasarkan } \\
\text { Mengambil }\end{array}$ \\
\hline No & \multicolumn{1}{c}{ Ketepatan } & $\mathrm{N}$ & $\%$ \\
\hline 1 & $\begin{array}{l}\text { Tidak memutuskan untuk } \\
\text { adopsi }\end{array}$ & 2 & 5,4 \\
2 & $\begin{array}{l}\text { Tepat jika dipengaruhi } \\
\text { lingkungan } \\
\text { Tepat jika dipengaruhi } \\
\text { orang yg berpengaruh }\end{array}$ & 10 & 27,0 \\
4 & $\begin{array}{l}\text { Belum tentu tepat tapi } \\
\text { keputusan sendiri }\end{array}$ & 13 & 32,5 \\
\hline & Jumlah & 37 & 100,0 \\
\hline
\end{tabular}

Sejumlah responden $(32,5 \%)$ mengakui bahwa mereka akan lebih tepat dalam mengadopsi alat tangkap apabila responden sering bertanya pada orang yang berpengaruh (misalnya nelayan panutan, pengumpul atau petugas dinas perikanan). Hal ini diduga karena orang yang lebih berpengaruh tersebut telah merasakan keberhasilan penggunaan alat tangkap, serta telah mahir menggunakan alat tangkap baru tersebut. Jawaban ini memperlihatkan kecenderungan karakteristik pelopor dan penerap awal. Adapun 27,0\% memperlihatkan kecenderungan penerap akhir, di mana mereka merasa tepat dalam mengambil keputusan untuk menggunakan alat tangkap baru setelah melihat sebagian besar nelayan menggunakannya. Terakhir adalah jawaban yang mencerminkan kelompok laggard, yang menyebutkan bahwa mereka sama sekali tidak tertarik untuk memutuskan menggunakan alat tangkap baru.

\section{Kesimpulan}

Secara teoritis, kategori adopter dimulai dari inovator (perintis), early adopter (pelopor), early majority (penerap awal), late majority (penerap akhir) dan laggard (penolak/kelompok lamban). Dari semua karakteristik adopter yang ditanyakan pada responden, tingkat kesukaan dalam mencoba teknologi 
baru dan tingkat kebutuhan akan dukungan/pihak lain dalam menerapkan teknologi baru memperlihatkan kondisi atau sebaran yang normal. Artinya jawaban-jawaban tersebut mewakili persentase jawaban responden apabila dikategorisasikan berdasarkan kategori adopter sesuai sebagan dengan kategori adopter yang dikemukakan Roges dan Shoemaker. Namun demikian, ternyata dalam wilayah penelitian ditemukan ciri khas tersendiri dari pribadi nelayan, yaitu lebih berani dalam memutuskan adopsi inovasi. Hal ini mungkin memperlihatkan ketangguhan jiwa nelayan yang siap menghadapi keadaan apapun, sesuai dengan ciri pelaut yang berani mengarungi lautan seluas apapun untuk memperoleh hasil tangkapan.

\section{Daftar Pustaka}

Departemen Pertanian. 2001. Penyuluhan Pertanian. Jakarta: Yayasan Pengembangan Sinar Tani.

KEPAS. 1992. Pola Umum Sistem Perikanan Tangkap Pantai Utara Pulau Jawa. Balitbang Pertanian. Jakarta: Departemen Pertanian.

Pangemanan, A.P., dkk. 2002. Sumber Daya Manusia (SDM) Masyarakat Nelayan. Bogor: Institut Pertanian Bogor

Pertiwi, P. R. 1994. Stratifikasi Sosial Masyarakat Nelayan dan Difusi Teknologi Penangkapan Ikan. Bogor: Institut Pertanian Bogor.

Rogers EM, Schoemaker FF. 1995. Communication of Innovations: A Cross Cultural Approach. Revised Edition. New York: The Free Press. 